\section{Obituary}

Check for updates

\section{OPEN ACCESS}

Received: Jan 28, 2019

Accepted: Jan 29, 2019

Address for Correspondence:

Sung-Tae Hong, MD, PhD

Department of Tropical Medicine and

Parasitology, Seoul National University College

of Medicine, 103 Daehak-ro, Jongno-gu,

Seoul 03080, Korea.

E-mail: hst@snu.ac.kr

(C) 2019 The Korean Academy of Medical

Sciences.

This is an Open Access article distributed under the terms of the Creative Commons Attribution Non-Commercial License (https:// creativecommons.org/licenses/by-nc/4.0/) which permits unrestricted non-commercial use, distribution, and reproduction in any medium, provided the original work is properly cited.

ORCID iDs

Jong-Min Kim (D)

https://orcid.org/0000-0001-5723-3997

Sung-Tae Hong (iD)

https://orcid.org/0000-0002-0300-1944

Disclosure

The authors have no potential conflicts of interest to disclose.

\section{Author Contributions}

Conceptualization: Kim JM, Hong ST. Data curation: Kim JM, Hong ST. Methodology: Kim JM, Hong ST. Writing - original draft: Kim JM, Hong ST. Writing - review \& editing: Kim JM, Hong ST.

\title{
In Memoriam: Professor Seung-Yull Cho (1943-2019)
}

\author{
Jong-Min Kim (1), Associate Editor, Journal of Korean Medical Science and \\ Sung-Tae Hong $(\mathbb{D}$, Editor-in-Chief, Journal of Korean Medical Science
}

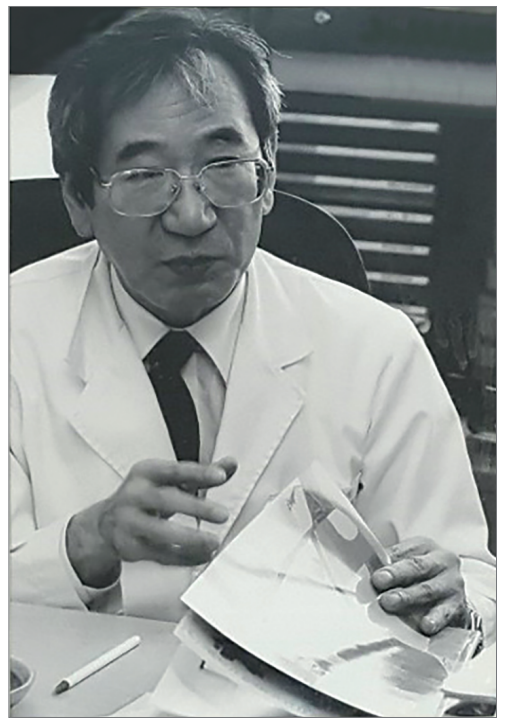

Seung-Yull Cho, MD, PhD, the former Editor-in-Chief of the Journal of Korean Medical Science (1997-2006), passed away on January 27, 2019 at the age of 75. He was born in Seoul on November 16, 1943. He graduated from Seoul National University College of Medicine in 1968, and he became a parasitologist. His professional career began at Department of Parasitology Seoul National University (1974-1981), but later he worked as Professor of Parasitology at Chung-Ang University (Dean, College of Medicine in 1992-1995), at the Catholic University of Korea, and at Sungkyunkwan University. After he retired at Sungkyunkwan University in 2009, he continued teaching at Gachon University. He contributed as the President of the Korean Society for Parasitology (1988-1989), the Korean Association of Medical Journal Editors (2002-2005), and the National Academy of Medicine of Korea (2010-2013).

Professor Cho published about 300 research articles on parasitology. He investigated chemotherapeutic control of enterobiasis, epidemiology of human ascariasis, serological tests of helminthiases, and other translational research. Thanks to his excellent scientific achievements, many patients with tissue invading helminthiases could make accurate diagnosis.

Professor Cho's accomplishments covered a wide array of fields. In addition to the field of parasitology, he also made a great professional contribution to publication of medical 
journals. To improve the quality of Korean medical journals, he initiated organizing the Korean Association of Medical Journal Editors in 1996 with many colleague editors of Korean medical journals and laid out a firm foundation for publishing medical journals in Korea. He was a role model Editor-in-Chief of Journal of Korean Medical Science from 1997 to 2006.

Professor Cho had enjoyed working hard through his life. Especially he was an ardent reader of manuscripts and legendary editor of journals. He continuously reviewed accepted manuscripts of the Journal of Korean Medical Science as an editorial adviser after leaving the editorial office in 2006. He devoted his whole life in Korean medical science as a type philologist. He was humble and austere personally but strict in science and editing. He is the 'seonbi' of the era, which is a Korean term for a great scholar with social acknowledgment. He gave us hope and courage. He will be remembered forever with sincere esteem and love. 